\title{
Autarkic tendencies in the Council for \\ Mutual Economic Assistance
}

\author{
Jerzy $€ A Z O R$ \\ Wojciech MORAWSKI
}

\begin{abstract}
Autarky was an important part of the Soviet economic model which emerged in the early 1930s. After this model had been forced onto other Eastern European countries during the Szklarska Poręba Conference in 1947, the economy of the entire Eastern Bloc started showing strong autarkic tendencies. Surprisingly, they did not imply autarky within the Bloc as a whole, but within each communist country on its own. From a geopolitical point of view this was an irrational move. USSR would have profited more from satellite countries with economies complementary to its own, rather than just copies of its regime. Autarkic tendencies proved to be a constant feature of the Eastern Bloc, despite attempts at reforms. The pursuit of self-sufficiency in each country soon moved down all the way to the microeconomic level. While rational there, it proved disastrous macroeconomically and paved the way for the system's subsequent demise.
\end{abstract}

Keywords: shortage, autarky, Soviet, communism, economy

Many public issues in the Eastern bloc became the subject of jokes. The so called 'socialist integration' was no exception. In one memorable example, the inefficiency of the Council of Mutual Economic Assistance (CMEA) was ironically explained with 'Russian honesty, Polish sobriety, the power of Cuban industry, German sense of humour and the use of Hungarian as the official language'.

The joke, however stereotypical, tries to identify some reasons behind the Soviet bloc's meagre economic integration. Our goal in this paper is broadly similar. Since our interests lay in the foundation of the system, rather than in its later evolution, we will restrict ourselves to the time before the fall of Krushchev. We aim to show that the communist system in Central and Eastern Europe was governed by emergent economic and social mechanisms, which promoted autarky on progressively lower levels. In particular, we believe that autarky first emergedin the bloc when stalinism was forced onto Soviet satellites in the lat 1940s, the second time was the result of economic and political reforms of the 1950s, and the third (perhaps not chronologically) was caused by the growing impact of shortage on communist economies.

Two elements of Stalin's post-NEP system had far-reaching consequences for our interpretation of the emergent mechanism in the Eastern Bloc: the idea of 'socialism in one country', and terror.

1 The authors would like to thank dr. Andrzej Zawistowski for sharing his immense knowledge of communist-era jokes. 
Whereas in other totalitarian regimes autarky could be considered a goal motivated mostly by military doctrine, in the case of the USSR it was an integral part of the economy. It was argued, that the only socialist country should not be dependent on capitalist states. Self-sufficiency was combined with over-investment in heavy industry, underdevelopment of light industry, collectivisation of land, and central planning, to transform the economy into 'one big factory', independent from the rest of the world and its crises, and theoretically free from the cost of competition.

The economic use of terror can be understood in a number of ways. The brutal transformation of Soviet society wouldn't have been possible without the fear terror produced. Moreover, Stalinism abolished market elements, which had played such an important role in the NEP. In theory, the market uses egoism of individual homini oeconomici, which through the invisible hand of the market, transcends individual needs. The Soviet system lacked this mechanism, and needed different stimuli to achieve results. The economy can be understood to have operated on a top-down (rather than bottom-up) basis, in which 'altruism' was promoted by ideology and terror. The latter was considered crucial - at least officially - because the system was being built by a society rooted in the previous system. When the society moved to communism, terror would have no longer been necessary.

The fundamental element of (both pre- and post-war) communist terror was its irrationality. Irrationality differentiates terror from oppressiveness. The former keeps the population in fear, by convincing citizens that anyone can be accused of anything. The latter loses much of its effectiveness, as rational strategies can be devised to avoid it. Under Stalin's rule no such strategies could be devised: neither staying out of politics nor engaging in the party's activities worked. Ideological heresy was easy to prove even to the most loyal communists. Stalin likened the party to a living organism, needing to replace its cells before they died off by themselves. ${ }^{2}$ The purge became a crucial socio-political institution. As the majority of the population lived in abject poverty and belonging to the ruling class was the only way to achieve a higher level of living, a place in the party apparatus was both desirable and dangerous. Thus terror slowed the process of petrification of the ruling class, but did not prevent its appearance. ${ }^{3}$

Despite Stalin's (arguably overquoted) declaration to Djilas, ('whoever occupies a territory also imposes his own social system. Everyone imposes his own system as far as his army can reach. It cannot be otherwise ${ }^{4}$ ), the first years after the

2 Jerzy Holzer, Europa zimnej wojny, Warszawa: Znak, 2012, p. 144.

3 Moreover, according to some historians, purges allowed Stalin to promote 'young, more vigorous and educated staff [which] could give a new impulse to the economic development', Khlevnyuk Oleg, "Economic Officials in the Great Terror, 1936-1938", in Melianie Ilič (ed.), Stalin's terror revisited, Houndmills-New York: Palgrave Macmillan, 2006, pp. 39-41, 63.

4 Milovan Djilas, Conversations with Stalin, trans. Michal B. Petrovich, New York: Harcourt Brace \& World, 1962, p. 114. 
second world war were a period of transition, when a number of scenarios seemed plausible. On the one hand, the future of communism in France and Italy looked promising, on the other, local communist party leaders in Central and Eastern Europe considered variations on the stalinist theme adapted to local situations, communist in their ideas, but built in a somewhat different manner - the so called national roads to socialism ${ }^{5}$.

This period, which did not serve the coherence of Stalin's new 'external empire' in Europe, came to a close soon after the Marshall Plan had been proposed. Using John Gaddis' term, Stalin needed to improve his methods of imperial management ${ }^{6}$. This was done through ideological integration of communist parties, started with the conference in Szklarska Poręba in September 1947, which saw the creation of the Information Bureau of Communist Parties (Cominform). During his conference speech, chief Soviet ideologue Andriej Zhdanov: 'main mouthpiece of the new world view" ${ }^{7}$, painted of a vision of the world devided into two opposing blocs. ${ }^{8}$ This marked the beginning of a bloc-wide stalinisation, which could be seen particularly strongly in 1948. With stalinism considered immutable, local communists were no longer free to rearrange its components. As a result, the political system in satellite states was cloned from the USSR, rather than adapted. It was - as Adam Zwass put it - a perverse implementation of the early modern cuius regio, eius religio. Forced stalinisation extended to all aspects of life - politics, literature, music and architecture were to look the same in Berlin, Warsaw, Budapest, Moscow or Magnitogorsk. Terror spread west ${ }^{9}$, and with it

5 John Lewis Gaddis, We Now Know. Rethinking Cold War History, Oxford: Claredon Press, 1997, pp. 14, 203; Adam Zwass, The Council for Mutual Economic Assistance. The Thorny Path from Political to Economic Integration, Armonk-London: M.E. Sharpe, 1989, pp. 12-13, Andrzej Skrzypek, Mechanizmy uzależnienia. Stosunki polsko-radzieckie 19441957, Pułtusk: Wyższa Szkoła Humanistyczna, 2002, pp. 182-187; Tadeusz Kowalik, Spory o ustrój społeczno-gospodarczy w Polsce. Lata 1944-1948, Warszawa: Wydawnictwo Key Text \& Instytut Nauk Ekonomicznych PAN, 2006, p. 116.

6 Gaddis, We Now Know, p. 46; Henryk Bartoszewicz, Polityka Zwiazku Sowieckiego wobec państw Europy Środkowo-Wschodniej w latach 1944-1948, Warszawa: Książka i Wiedza, 1999 , p. 7.

7 Vladislav Zubok and Constantine Pleshakov, Inside the Kremlin's Cold War: from Stalin to Khrushchev, Cambridge-London: Harvard University Press, 1996, p. 111; Vojtech Mastny, Stalin i zimna wojna. Sowieckie poczucie bezpieczeństwa, trans. Małgorza Werner, Warszawa: Trio, 2006, pp. 61-64.

8 Werner G. Hahn, Postwar Soviet Politics. The Fall of Zhdanov and the Defeat of Moderation, 1946-1953, Ithaca-London: Cornell University Press, 1982, p. 98; Baroszewicz, Polityka, pp. 322-332.

9 'If the Nazi caught you as a political dissident, they usually wanted to know what you did, who your friends were, what were your plans etc. The Communists did not go for that. They already knew, when they arrested you, what kind of confession you were going to sign', Jacques Rupnik, The Other Europe. The Rise and Fall of Communism in East-Central 
- purges, waves of which occurred to different degrees in all countries of the bloc. Economic elements of the new system included over-investment in heavy industry, forced collectivisation of land and, crucially, central planning. ${ }^{10}$

One element of forced stalinisation was particularly interesting: a deeply ingrained seeking of self-sufficiency on a country level. Moreover, each state was to follow the same basic development path. ${ }^{11}$ This was a paradox: at the same time it strengthened ideological coherence and loosened potential economic ties. If the USSR wanted to exploit its 'external empire' more efficienctly, it would have made more sense to make the satellites specialise in products the Soviets particularly needed. ${ }^{12}$

This effect was strengthened by the evolution of intra-bloc trade. While there were huge differences between such countries as Czechoslovakia and Romania, in general they had substitute rather than complementary economies. This is confirmed by a low level of trade between them before the second world war (excluding the USSR, no more than $10 \%$ of their total $\operatorname{trade}^{13}$ ). The forceful adoption of very similar development paths after 1947 only strengthened their substitute character. ${ }^{14}$ The USSR forced new trade relations, which followed a hub-and-spoke model, with the Soviets acting as the hub, and trade between satellite countries remaning relatively small (which was also the model for political relations in the bloc). Exchange was mostly based on middle-term bilateral agreements, which tied new communist countries to the USSR. ${ }^{15}$ As Ivan T. Berend put it (writing about a sli-

Europe, New York: Pantheon Books, 1989, p. 113; George Hodos, Show Trials: Stalinist Purges in Eastern Europe 1948-1954, New York: Praeger, 1982.

10 Zwass, The Council, p. 4; Skrzypek, Mechanizmy uzależnienia, pp. 227-222, 234-239; János Kornai, The Socialist System. The Political Economy of Communism, Princeton: Princeton University Press, 1992, pp. 111-130; Ben Fowkes, The Rise and Fall of Communism in Eastern Europe, 2nd ed., Houndmills-London: Macmillan Press, 1995, pp. 52-65; Jacek Luszniewicz, "Wzorzec radziecki a system Polski w latach 1944-1956. Odwzorowanie, modyfikacja czy rewizja", Konrad Rokicki, Sławomir Stępień (eds), W objęciach wielkiego brata. Sowieci $w$ Polsce 1944-1993, Warszawa: Instytut Pamięci Narodowej, 2009, pp. 95-122.

11 Zwass, The Council, p. 8.

12 That is not to say that severe exploitation did not take place, Bartoszewicz, Polityka, pp. 227-269.

13 Cecylia Leszczyńska, “Socjalistyczny neomerkantylizm. System rozliczeń obrotów płatniczych między państwami socjalistycznymi w latach 1945-1970”, in: Jachowicz Piotr (ed.), W poszukiwaniu modelu gospodarki centralnie kierowanej, Warszawa: Oficyna Wydawnicza Szkoły Głównej Handlowej w Warszawie, 2013, p. 110; Zwass, The Council, p. 6; Ivan T. Berend, Decades of Crisis. Central \& Eastern Europe Before World War II, Berkeley-Los Angeles-London: University of California Press, 1998, pp. 271-272.

14 Antoni Marszałek, Planowanie $i$ rynek $w$ RWPG. Geneza niepowodzenia, Łódź: Wydawnictwo Uniwersytetu Łódzkiego, 1993, p. 22.

15 Skrzypek, Mechanizmy uzależnienia, p. 200; Gaddis, Now We Know, p. 204; Holzer, Europa, p. 340; Valerie Bunce, Subversive Institutions. The Design and the Destruction of Socialism and the State, Cambridge-New York: Cambridge University Press, 1999, pp. 39-40. 
ghtly later period): 'the most negative effect of this isolationist „Socialist-Worldmarket" was its contribution to the realization of the autarkic orientation, which would not have been possible in international frameworks'. ${ }^{16}$

In communist states, there were no market mechanisms to stimulate producers. As a result, international trade additionally sanitised by an inconvertible currencies, did not help the economy, as it promoted neither specialisation nor innovation. ${ }^{17}$ The value of goods exchanged, usually via barter, was entirely detached from cost. Satellite states could consider exports to the USSR as an abstract tax put on the economy. If temples of a strange cult had suddenly been erected in Prague, Warsaw, and Berlin, with their priests demanding coal and machines in exchange for oil, the economic effect would not have been much different. Especially since the quality of these machine didn't matter as much as on a real market. In such a system exports can at most be considered a way to finance imports of needed materials, and self-sufficiency is sought whenever possible. This was exacerbated by the fact that without a convertible currency, communist countries pursued not only general bilateral balance of payments with each state, but also aimed to achieve it within individual product groups being traded with this state. Thus exports of raw materials had to be met by other prioritised items, such as machines ${ }^{18}$, and no advanced export policy could be implemented.

The founding of the Council for Mutual Economic Assistance (CMEA, Comecon) in 1949 changed very little. It can be argued that the organisation was created for purely political reasons ${ }^{19}$, as a formal alternative to the Marshall plan, and a means of 'freeing' the socialist countries from 'Western economic discrimination' ${ }^{20}$. During Aleksey Lavryshchev's brief time as CMEA's secretary, it showed some action, but under Mikoyan it was little more than a name. ${ }^{21}$ No new meetings were called until 1954, and as Jens Hacker put it, most of what the organisation did before Stalin's death, was to fervently boycott Tito's Yugoslavia. ${ }^{22}$

16 Ivan T. Berend, Central and Eastern Europe 1944-1993. Detour from the periphery to the periphery, Cambridge-New York: Cambridge University Press, 1996, p. 82.

17 Leszczyńska, "Socjalistyczny neomerkantylizm”, p. 115.

18 Henryk Różański, Spojrzenie na RWPG. Wspomnienia-dokumenty-refleksje 1949-1988, Warszawa: Wydawnictwo Naukowe PWN, 1990, pp. 60-61; Kazimiera Wilk, Integracja wschodnio-europejska. Powstanie, funkcjonowanie i upadek, Wrocław 1994, p. 111; Berend, Central and Eastern, pp. 77-78.

19 The first Secretary of the CMEA did not receive documents concerting its founding, as in the USSR they had been classified as secret and obtaining them would have required a complicated procedure. Instead, he unofficially copied them from his Polish and Hungarian colleagues, Różański, Spojrzenie, p. 20.

20 And it's official goals were fairly modest: 'exchanging economic experience and providing mutual technical assistance as well as assistance in raw materials, foods, machinery and equipment', Zwass, The Council, pp. 9-15; Skrzypek, Mechanizmy uzależnienia, pp. 232-233

21 Dissenting views: Różański, Spojrzenie, pp. 37-38, 43; Fowkes, The Rise and Fall, pp. 61-62.

22 Quoted in Holzer, Europa, p. 336. 
Interestingly, as Stalin controlled the states of the blocs through other means, CMEA was officially founded on the principles of sovereign equality of all members and required unanimous decisions on all matters. This played a role in future discussions within the Council. ${ }^{23}$

Stalin's death had important consequences for autarkic tendencies, particularly through the abolishment of terror and economic decentralisation.

During his famous secret speech during the 20th Congress of the Soviet Communist Party in 1956, Khrushchev condemned some 'abuses' of the previous system: in particular its use of terror against communists. His critique ushered in a new approach. From now on a communist leader could retire and die in his bed, rather than at the hands of his successor. While Beria had been executed in 1953, Khrushchev let Malenkov live not only after his deposition from the post of prime minister in 1955, but also after the party opposition's revolt in 1957 . This policy became an integral part of the system, as Krushchev himself was not killed in 1964. With some minor exceptions (such as Hungary after 1956), this spread to other countries of the bloc. The purge as an institution was abolished. 'Obscurity rather than death awaited the losers'. ${ }^{24}$

Terror was also rescinded on a more general scale. The system was no longer random: it was now possible to develop strategies to keep out of harm's way. Instead of terrorising the population, it now served as a (very oppressive) deterrent. The system certainly certainly remained a totalitarian regime, but its character noticeably changed. ${ }^{25}$

This had a tremendous effect. By giving party members personal safety, it allowed the nomenklatura to calcify to a much greater degree than under Stalin ${ }^{26}$. With decalcifying mechanisms gone, but party privileges intact, this accelerated the creation of a safe, egoistic bureaucratic class. To use a metaphor from a different era, it was not unlike the creation of a feudal class, now given a personal privilege of safety - like a medieval neminem captivabimus of sorts. It introduced a certain amount of independence - a greater possibility for pursuing self-sufficiency should it be to one's advantage. Perhaps most tellingly, terror was not abolished, as the utopian vision predicted, with the establishment of 'real communism', but rather as a part of a process of feudalisation of the Soviet society. This effect could be seen on a local, state and international level.

The abolishment of terror on a country level coincided with changes to the economy. Malenkov, who played a leading role in 1953-1955, questioned the dominance of heavy industry. Krushchev's vision followed a somewhat different path.

23 Różański, Spojrzenie, p. 16.

24 Charles Gati, The Bloc that Failed. Soviet-East European Relations in Transition, Bloomington-Indianapolis: Indiana University Press, 1990, p. 30.

25 Holzer, Europa, p. 458.

26 Fowkes, The Rise, pp. 64-65. 
His reforms had a certain incoherence, somewhat parallel with the development of socialist economic theory at the time (works by Oscar Lange, Michał Kalecki and Aleksy Wakar, to look just at Polish examples ${ }^{27}$ ). While too great centralisation had come under attack, this did not extend to even a slight rehabilitation of market forces (like within the New Economic Policy). Both the central planner or workers' committees were assumed to be altruistic. Central planning, rather than abolished, was to be perfected by allowing lower-level cadres to participate in the process.

Reforms followed, to a certain degree, this point of view. Basic ideas behind the system were not challenged: the economy would still be owned by the state, and governed by central planning. The questioned element was the 'one big factory' paradigm. In general, too great a degree of centralisation was now considered a hurdle for effectiveness, in particular with the difficulty of high-level bureaucracy to take decisions and the ineffectiveness of the all-powerful ministries.

Tito's policy had, of course, been an early example of this trend, with self-management of state-owned companies playing an important role, but Yugoslavia remained outside of the CMEA. A swiftly aborted experiment on the Yugoslavian theme could be seen in post-October Poland, but the defining experience of communist decentralisation came with Soviet reforms.

Soviet central ministries, as Philip Hanson writes, 'had been guilty of "departamentalism" (vedomstvennost): a narrow preoccupation with the concerns of one's economic branch... it meant a tendency for the objectives of the individual ministry's empire to prevail over those of the national economy as a whole' ${ }^{28}$ Vedomstvennost can be considered a form of economic disintegration, caused by central planning. The decentralisation reform meant to address this problem, by relegating a degree of decision-making to the level of regions. Accordingly, starting in 1957, 105 Regional Economic Councils (sovnarkhozy) were created, closely matching the divisions of local party administration. This did not imply giving any power to managers of enterprises: all decisions were taken on the region level, with local party leaders 'playing a stop-gap role, chasing up inputs for local producers'. ${ }^{29}$ As Adam Zwass put it, 'the local patriotism generated by the regional administrations did more damage to the economy than did the self-centred tendencies of the economic ministries'. ${ }^{30}$ Together with political changes, it gave birth

27 Oscar Lange, O socjalizmie $i$ gospodarce socjalistycznej, Warszawa: Wydawnictwo Naukowe PWN, 1966; Michał Kalecki, Zarys teorii wzrostu gospodarki socjalistycznej, Warszawa: Wydawnictwo Naukowe PWN, 1963; Aleksy Wakar, Morfologia bodźców ekonomicznych, Warszawa: Wydawnictwo Naukowe PWN, 1963.

28 Philip Hanson, The Rise and Fall of the Soviet Economy: An Economic History of the USSR From 1945, Harlow: Pearson Education, 2003.

29 Peter Rutland, The Politics of Economic Stagnation in the Soviet Union: The Role of Local Party Organs in Economic Management, New York: Cambridge University Press, 1992, p. 75 .

30 Zwass, The Council, p. 30. 
to the first emergent mechanism. Without the use of terror it became increasingly difficult to force the local cadres into obedience, as they followed their own goals. Again using a feudal analogy, this can be compared to the bureaucracy gaining a form of economic privilege, not unlike feudal lords acquiring greater control of their fiefdoms at the cost of the ruler.

This situation was soon contested by the state, and already in 1962 the number of sovnarkhozy was lowered to 47 , which aimed to reduce the power of regional party officials. From and economic and administrative perspectives, much more interesting conflicts occurred not between communist parties and society at large, but rather within the power structures themselves ${ }^{31}$, with a particular tension between the centre and lower cadres. The former aimed to protect its position and power, why the latter fought for para-feudal privileges. This conflict was one of the reasons behind the system's inherent resistance to reforms. This inertia also owed much to the overgrowth of the heavy industries sector, which was able to put immense pressure on the system.

Regionalisation resulted in chaos and additional supply problems. Its failure found the most dramatic expression in the Novocherkassk massacre in June 1962, when a revolt was drowned in blood by the military. ${ }^{32}$ When Krushchov fell two years later, central ministries were immediately brought back. On a larger time scale, the economy went into a cycle of reforms and counter-reforms ${ }^{33}$, but the development of autarky was difficult if not impossible to tackle without the help of market mechanism - and those did not come before Ghorbachev.

Policy changes against terror and centralisation reacted with another inherent element of communist economy: as Kornai so eloquently showed, planning resulted in an economic system consistently plagued by shortage. ${ }^{34}$ At the same time, decentralisation reforms introduced more egoistic behaviours. It can be (and has been) argued that market behaviours arose even with what little leeway people in the communist countries were given. It was something we'd like to call the mutilated market - that is a market in which shortage was ever present and market behaviours were counter-system.

Shortage in such a situation has a peculiar property - it leads to autarky. Its most obvious symptom is the unreliability of markets. A buyer is never guaranteed to receive what he seeks. In the case of consumers (if one might use this term in reference to citizens of socialist countries) and products with low price

31 Bunce, Subversive, p. 36 shows that the Soviet institutions inherently generated these conflicts.

32 Zubok and Pleshakov, Inside the Kremlin, pp. 263-264.

33 Zbigniew Landau, "Etapy rozwoju Polski Ludowej”, Przegląd Historyczny 78 (1987), 2, pp. 211-250.

34 János Kornai, Economics of Shortage, Amsterdam-New York: North Holland, 1980; idem, The Socialist System. 
elasticity of demand, in the short term it might mean turning to the black market. Non-crucial products might simply be foregone. In a longer scope of time various para-market behaviours might be sought, be it barter or bribes. The very same mechanism applied to economic regions or production plans of single enterprises. If the well-being of their management depended on meeting a centrally predetermined set of parameters, managers would turn to unofficial channels to procure the needed resources. This was evident in the fact that newly built factories found it more difficult to operate: they lacked, as Peter Rutland puts it, an established network of contacts. ${ }^{35}$ This process was of course visible under Stalin, as the threat of death forced managers to seek alternative ways of reaching plans, but the process took on a new rapidity as local activists gained greater independence and structures began to settle. In the long term, ministries and individual enterprises sought samosnabzhenie ('self-supply'), to mitigate these shortage-induced problems. In other words, the seeking of autarky spread ever lower, from country to region, from region to company and ultimately down to the level of individual households. Quoting I. Berend: 'Central planning and the lack of market incentives actually pushed each country and each firm toward self-sufficiency, in order not to be „dependent” on other non-interested countries that might and did cause permanent troubles by nont fulfilling or delaying deliveries, thus endangering the plan fulfilliment' ${ }^{36}$

This was famously shown by Stanisław Lem in short story about the adventures of Ijon Tichy. ${ }^{37}$ The hero finds himself in an African country in which shortage is king. A rational solution to its woes is to have as many children as possible and either educate them, or marry off to people working in key industries - from healthcare through plumping through food production to - ultimately - funerary services. Each extended family becomes self-sufficient, but at the cost of paralysing high-level functions of the economy.

Shortage made this process rational on a microeconomic level, but drove the Soviet economy into stagnation. We believe that the acceleration of this process was another emergent mechanism, with roots in Soviet economic an social reforms. This development makes one question the validity of calling the communist economy 'planned'. With successive changes, the centre had an ever limited array of methods of influencing sufficiency-seeking lower levels, which operated within the reality of a mutilated market, governed by shortage. Some parts of the economy (particularly the military-industrial complex) continued to grow in force and gained a form of immunity. Moreover, the centre found it progressively

35 Rutland, The Politics, p. 76. Those contacts often included the planning apparatus, Berend, Central and Eastern, pp. 75-76.

36 Berend, Eastern and Central, p. 192.

37 Stanisław Lem, "Profesor A. Dońda (Ze wspomnień Ijona Tichego)", in: idem, Dzienniki gwiazdowe: Wydanie rozszerzone, Kraków: Wydawnictwo Literackie, 1982, pp. 487-521. 
difficult to understand what was happening, as it operated in an abstract paradigm of political economy, useless in describing the real processes. ${ }^{38}$ Paradoxically, without the reintroduction of market mechanics, any reform aimed at democratising or decentralising the system would only serve to further the progress of autarky.

The problem of self-sufficiency was also easily visible on the international scale, and solutions were sought after Stalin's death. It was Krushchev who could be called the real father of the CMEA. During his years in the Kremlin, the organisation was brought back to life. Already the first meeting after Stalin's death in March 1954 provided it a broad set of long-term goals, while the summit in May 1958 introduced formal statutes and a more robust institutional structure. ${ }^{39}$

As mentioned above, a model of 'socialist co-operation' where all the countries follow the same development pattern and produce broadly the same set of products wasn't optimal, and resulted in a propensity for autarky in the economy. Without Stalin's steel grip, even political paths of individual countries began to diverge ever so slightly. Krushchev saw economic integration as one way of keeping the bloc closely knit.

An alternative to Stalin's vision of the bloc would include specialisation between CMEA member countries, or, as it was called, 'socialist division of labour'. This was not easy to introduce - the idea of specialisation was at odds with the basic precepts of stalinism, and local communist leaders found to difficult to let go of certain key policies. In particular,it would force still predominantly rural countries like Romania to remain but foodstuff producers, serving more advanced states such as Czechoslovakia or the GDR. From USSR's point of view, this was a rational choice - it would have meant a fuller utilisation of its political power on the economic level. For poorer countries it would have been a disaster: a petrification of their economic structures. ${ }^{40}$

Until Krushchev's fall, there were two approaches to this type of greater specialisation. The first was based on plan co-ordination, in which countries would use the CMEA as a forum for aligning their plans. Indeed already the summit in 1954 criticised what it dubbed 'unjustified parallelism' of communist economies. This voice was heard throughout the 1950s. However, member countries were loathe to agree to a co-ordination of investment plans ${ }^{41}$, especially since it took a fairly

38 Kazimierz Kloc, "Narodziny ekonomii politycznej socjalizmu - perspektywa wewnątrzsystemowa", in: Jachowicz Piotr (ed.), W poszukiwaniu modelu gospodarki centralnie kierowanej, Warszawa: Oficyna Wydawnicza Szkoły Głównej Handlowej w Warszawie, 2013, pp. 42-48.

39 Zwass, The Council, pp. 17, 24-26, 34.

40 Skrzypek, Mechanizmy uzależnienia, p. 374; Zwass, The Council, p. 5.

41 Różański, Spojrzenie, p. 54; Skrzypek, Mechanizmy uzależnienia, p. 334; Andrzej Skrzypek, Mechanizmy autonomii. Stosunki polsko-radzieckie 1956-1965, Pułtusk: Wyższa Szkoła Humanistyczna, 2005, p. 41. 
crude form. Polish economist Henryk Różański recalled how it was enforced in the machine sector. Council clerks prepared a large table, in which each of around 600 columns represented different machines types, while the rows signified member states. The placements of crosses in cells determined the future of industries (some of them already existing) and was thus met with long and hard negotiations. Many elements of plan co-ordination were contested, but, when it seemed that it would go forward, in December 1958 Krushchev decided to let it go, surprising everyone during CMEA's $10^{\text {th }}$ meeting in Prague. His decision was motivated by the start of the decentralisation reform, which required recasting of all plans.

The second approach to forced integration was more severe. It originated with Gomułka's proposals ${ }^{42}$, and evolved from a co-ordination of plans, to a single unified plan, by relegating all planning within the CMEA to Soviet's Gosplan. Such a move - from an economic perspective - would turn member states into entities on the level of Soviet republics, following their centrally-determined 'selective development plan'. It should be noted, however, that particularly after the 20th congress, party leaders within the CMEA saw greater opportunity for negotiating their own positions..$^{43}$ Romania was the country which voiced its disagreement so effectively, that the reform was cancelled, and the CMEA temporarily lost much of its meaning, particularly after Krushchev's deposition. Adam Zwass argues that even had there been no disagreement, the organisation lacked mechanisms needed to introduce such a plan. On the international level, the initial drive for self-sufficiency was hard to overcome, despite subsequent tries. As countries had different levels of development, their economic integration goals were also differed. Only a centralised planning system could have forged them into a coherent unit, but that had only been possible during Stalin's times. ${ }^{44}$

To sum up, we believe that the propensity for autarky was an inherent attribute of the economic and social system introduced in European communist countries after the second world war. Reforms which came in the late 1950s only amplified this tendency. This outcome had not been planned by the people in power, but can be considered an emergent behaviour of actions aiming to ameliorate the system. In a way, the communist economy turned out to be, starting from the 1950 s, less centrally planned, and less dependant on top-level political decisions than it seemed.

42 Różański, Spojrzenie, pp. 135-159; Skrzypek, Mechanizmy autonomii, pp. 253-256; Wojciech Morawski, "Poglądy gospodarcze Władysława Gomułki”, in: Elżbieta Kościk, Tomasz Głowiński (eds), Gospodarka i społeczeństwo w czasach PRL-u (1944-1989), Wrocław: Gajt, 2007, pp. 326-332; Zwass, The Council, p. 40.

43 As Henryk Różańki put it, "Doubtlessly, when Stalin was alive many would not have had the courage to disagree", Różański, Spojrzenie, pp. 62, 81-88, 93; Skrzypek, Mechanizmy autonomii, p. 164; Skrzypek, Mechanizmy uzależnienia, p. 375; Gaddis, Now We Know, p. 208.

44 Ibidem, p. 10-11, 186; Różański, Spojrzenie, pp. 165-185; Skrzypek, Mechanizmy autonomii, p. 261. 


\section{Bibliography}

Bartoszewicz, Henryk (1999), Polityka Zwiazku Sowieckiego wobec państw Europy ŚrodkowoWshodniej w latach 1944-1948, Warszawa: Książka i Wiedza.

Berend, Ivan T. (1996), Central and Eastern Europe 1944-1993. Detour from the periphery to the periphery, Cambridge-New York: Cambridge University Press.

Berend, Ivan T. (1998), Decades of Crisis. Central \& Eastern Europe Before World War II, Berkeley-Los Angeles-London: University of California Press, 1998.

Bunce, Valerie (1999), Subversive Institutions. The Design and the Destruction of Socialism and the State, Cambridge-New York: Cambridge University Press.

Brzeziński, Zbigniew (1990), The Grand Failure. The Birth and Death of Communism in the Twentieth Century, London-Sydney: Macdonald.

Cambell, John C. (1984), „Soviet Policy in Eastern Europe: an Overview”, in: Sarah Meiklejohn Terry (ed), Soviet policy in Eastern Europe, New Haven-London: Yale University Press.

Davis, Robert W. (2006), „The Soviet Econonomy and the Launching of the Great Terror”, in: Stalin’s Terror Revisited, ed. Melianie Ilič, Houndmills-New York: Palgrave Macmillan, 11-37.

Fowkes, Ben (1995), The Rise and Fall of Communism in Eastern Europe, $2^{\text {nd }}$ ed., HoundmillsLondon: Macmillan Press.

Gaddis, John Lewis (1997), We Now Know. Rethinking Cold War History, Oxford: Claredon Press.

Gati, Charles (1990), The Bloc that Failed. Soviet-East European Relations in Transition, Bloomington-Indianapolis: Indiana University Press.

Hahn, Werner G. (1982), Postwar Soviet Politics. The Fall of Zhdanov and the Defeat of Moderation, 1946-1953, Ithaca-London: Cornell University Press.

Hanson, Philip (2003), The Rise and Fall of the Soviet Economy: An Economic History of the USSR From 1945, Harlow: Pearson Education.

Hodos, George (1982), Show Trials: Stalinist Purges in Eastern Europe 1948-1954, New York: Praeger.

Holzer, Jerzy (2012), Europa zimnej wojny, Warszawa: Znak.

Landau, Zbigniew (1987), “Etapy rozwoju Polski Ludowej”, Przegląd Historyczny 78, 2, 211-250.

Lange, Oscar (1966), O socjalizmie i gospodarce socjalistycznej, Warszawa: Wydawnictwo Naukowe PWN.

Lem, Stanisław (1982), "Profesor A. Dońda (Ze wspomnień Ijona Tichego)”, in: idem, Dzienniki gwiazdowe: Wydanie rozszerzone, Kraków: Wydawnictwo Literackie, 487-521.

Leszczyńska, Cecylia, (2013), "Socjalistyczny neomerkantylizm. System rozliczeń obrotów płatniczych między państwami socjalistycznymi w latach 1945-1970”, in: Jachowicz Piotr (ed.), W poszukiwaniu modelu gospodarki centralnie kierowanej, Warszawa: Oficyna Wydawnicza Szkoły Głównej Handlowej w Warszawie, 107-124.

Luszniewicz, Jacek (2009), "Wzorzec radziecki a system Polski w latach 1944-1956. Odwzorowanie, modyfikacja czy rewizja”, Konrad Rokicki, Sławomir Stępień (eds), $W$ objęciach wielkiego brata. Sowieci w Polsce 1944-1993, Warszawa: Instytut Pamięci Narodowej, 95-122. 
Jarosz, Dariusz (2013), „Mały indywidualizm”[!!!], in: Jachowicz Piotr (ed.), W poszukiwaniu modelu gospodarki centralnie kierowanej, Warszawa: Oficyna Wydawnicza Szkoły Głównej Handlowej w Warszawie.

Kalecki, Michał (1963), Zarys teorii wzrostu gospodarki socjalistycznej, Warszawa: Wydawnictwo Naukowe PWN.

Khlevnyuk, Oleg (2006), „Economic Officials in the Great Terror, 1936-1938”, in: Stalin's Terror Revisited, ed. Melianie Ilič, Houndmills-New York: Palgrave Macmillan, 38-67.

Kloc, Kazimierz (2013), "Narodziny ekonomii politycznej socjalizmu - perspektywa wewnattrzsystemowa”, in: Jachowicz Piotr (ed.), W poszukiwaniu modelu gospodarki centralnie kierowanej, Warszawa: Oficyna Wydawnicza Szkoły Głównej Handlowej w Warszawie, 29-50.

Kornai, János (1980), Economics of Shortage, Amsterdam-New York: North Holland.

Kornai, János (1992), The Socialist System. The Political Economy of Communism, Princeton: Princeton University Press.

Kowalik, Tadeusz (2006), Spory o ustrój społeczno-gospodarczy w Polsce. Lata 1944-1948, Warszawa: Wydawnictwo Key Text \& Instytut Nauk Ekonomicznych PAN, 2006.

Marszałek, Antoni (1993), Planowanie i rynek w RWPG. Geneza niepowodzenia, Łódź: Wydawnictwo Uniwersytetu Łódzkiego.

Morawski, Wojciech (2007), „Poglądy gospodarcze Władysława Gomułki”, in: Elżbieta Kościk, Tomasz Głowiński (eds), Gospodarka i społeczeństwo w czasach PRL-u (1944-1989), Wrocław: Gajt, 326-332.

Mastny, Vojtech (2006), Stalin i zimna wojna. Sowieckie poczucie bezpieczeństwa, trans. Małgorza Werner, Warszawa: Trio.

Różański, Henryk (1990), Spojrzenie na RWPG. Wspomnienia-dokumenty-refleksje 1949-1988, Warszawa: Wydawnictwo Naukowe PWN.

Rupnik, Jacques (1989), The Other Europe. The Rise and Fall of Communism in East-Central Europe, New York: Pantheon Books.

Rutland, Peter (1992), The Politics of Economic Stagnation in the Soviet Union: The Role of Local Party Organs in Economic Management, New York: Cambridge University Press.

Skrzypek, Andrzej (2002), Mechanizmy uzależnienia. Stosunki polsko-radzieckie 1944-1957, Pułtusk: Wyższa Szkoła Humanistyczna.

Skrzypek, Andrzej (2005), Mechanizmy autonomii. Stosunki polsko-radzieckie 1956-1965, Pułtusk: Wyższa Szkoła Humanistyczna.

Wakar Aleksy, (1963), Morfologia bodźców ekonomicznych, Warszawa, Wydawnictwo Naukowe PWN.

Wilk Kazimiera, (1994), Integracja wschodnioeuropejska. Powstanie, funkcjonowanie i upadek, Wrocław: Wydawnictwo Akademii Ekonomicznej.

Zubok, Vladislav and Pleshakov, Constantine (1996), Inside the Kremlin's Cold War: from Stalin to Khrushchev, Cambridge-London: Harvard University Press.

Zwass, Adam (1989), The Council for Mutual Economic Assistance. The Thorny Path from Political to Economic Integration, Armonk-London: M.E. Sharpe. 